\title{
THE LAW OF ICY SIDEWALKS IN NEW YORK STATE.
}

The tendency in modern times of the inhabitants of our country to congregate in our great cities has enormousiy increased the population of our different municipalities, and this, in conjunction with the severe and changeable winter weather in the State of New York, and the consequent slippery and snowy condition of our sidewalks during several months of each year, has given rise to almost numberless litigations against our cities for injuries caused by falling on ice-coated and snowcovered sidewalks, and the law bearing upon this subject from a state of uncertainty has become fixed and certain.

It has been the common belief among the laity, that any person falling on an icy or snowy sidewalk, irrespective of its condition as to repair, or how long the snow and ice have remained on the sidewalk, can recover from the city in whose limits is situated the sidewalk on which he has fallen. It has been very commonly believed that our cities are sort of accident insurance companies to protect everyone against injuries occasioned by such accidents. The decisions of our courts have, however, very properly held otherwise, and it is the purpose of this article to recite briefly the present condition of the law of the Empire State bearing on this interesting question; a question which may become of importance to some of my readers.

Primarily it is the duty of every municipality to keep its streets, which includes the sidewalks, in a safe condition, suitable for the public use, and the city must exercise active vigilance in seeing that its streets are thus kept in the proper condition.

One of the earliest cases in our Court of Appeals on this question is that of Todd $v$. the City of Troy, reported in $6 \mathrm{r} N$. $\mathrm{Y}$. at page 506. Judge Earl in his opinion says: "It was the duty of the city under its charter to keep the streets in repair and in suitable condition for public travel, and any person suffering damage or injury, without any fault on his part, from a neglect of this duty, has a cause of action against the city." However, before any municipality can be held liable it must be 
shown that it had notice of the bad condition of the walk. This notice may be either actual or constructive. By actual notice is meant that some officer of the city had received notice of the condition of the walk. Judge Earl in his opinion in the case above referred to, says: "By constructive notice is meant such notice as the law imputes from the circumstances of the case. * * * They [the municipal authorities] cannot fold their arms and shut their eyes, and say they have no notice. After a street has been out of repair so that the defect has become known and notorious to those traveling the street, and there has been every opportunity for the municipality, through its agents charged with that duty, to learn of its existence and repair it, the law imputes to it notice and charges it with negligence."

One case, however, has held that notice to a policeman is not necessarily notice to the city because he was not deemed a proper officer of the municipality to acquire such notice. Another case, however, that of Twogood $v$. the Mayor, etc., of New York, ro2 N. Y. 2x6, holds that in an action for negligence in not causing an accumulation of ice to be removed from a sidewalk, the fact that a patrolman, who was on duty, had reported to the Inspector each day for several days prior to the injury complained of, that the snow and ice had not been removed from the sidewalk in question, and where it was the custom for these reports to be forwarded to police headquarters and from there to the office of the corporation counsel, was sufficient to charge the city with notice.

Although the city is required to use active diligence in keeping its sidewalks in proper repair so far as actual defects in their construction are concerned, it is incumbent upon it to exercise only what the law terms reasonable diligence to remove from its sidewalks ice which has formed during the existence of cold weather from natural causes.

In the case of Kaveney $v$. the City of Troy, reported in ro8 $\mathrm{N}$. Y., page 57I, the Court said: The city is not bound to the exercise of unreasonable, persistent and extraordinary diligence during freezing weather to remove ice formed from natural causes; it is simply bound to keep sidewalks reasonably clean and safe."

In Corbett $v$. the City of Troy, 53 Hun. 228, the evidence shows that a city hydrant was so constructed that water escaped therefrom and ran across the street, freezing upon the sidewalk and forming a layer of ice. Some snow fell the day before the accident, completely covering the formation of ice. The plain- 
tiff in this action could not see the ice because of the recent fall of snow. There was testimony tending to show that the ice had existed for some weeks prior to the accident, but this was disputed; but since the hydrant was shown to have been leaking, although the accumulation of ice may not have existed for a sufficient length of time to prove constructive notice to the city, the jury would have been justified in finding negligence on the part of the city in allowing the water to escape from the hydrant. The Court says in this case that it was not one where the ice was formed from what is known as natural causes, such as the freezing of rain or sleet, and the formation of the ice being the natural result of the escape of the water, the city might justly be found guilty of negligence.

The neglect of municipal duty must be very clear in order to hold the city liable for injuries caused by snow and ice. ${ }^{1} \mathrm{~A}$ city is not liable in damages for any injuries which are the results of the slippery condition of a sidewalk produced solely by ice which is of recent formation. ${ }^{2}$

It is, however, liable to any one using the sidewalk for injuries occasioned by an accumulation of ice which has been of long duration, provided no recent change in the temperature has caused the formation of a new coating of ice over the old accumulation, and which may have been the direct cause of the injury. Something more must always exist than the slippery condition of the sidewalk to allow a person to recover from a municipality.

The practitioner in New York State is oftentimes taken by surprise in the trial of an action for damages resulting from a fall on a slippery sidewalk. He brings an action on the statement of his client, and perhaps after careful examination of other witnesses, by whom he is assured that the accumulation of ice and snow has been of long duration, but on the trial he is met by the testimony of the Chief of the Weather Bureau, who with his records is able to give proof which cannot be rebutted, that during the day on which the accident happened the temperature has risen and fallen to such an extent that an entirely new coating of ice must have been formed during the very day of the accident. In such a case the courts say that there are two causes contributing to the accident; one the accumulation of ice and snow, which has been of sufficient duration to charge the municipality with constructive, if not actual notice, and

1 Pomfrey v. Saratoga Springs, I04 N. Y. page 459.

2 Kinney $v$. the City of Troy, 108 N. Y. 567. 
render the city liable for damages; the other, the recent coating of ice, for which the city is not liable, and in such a case the jury cannot be allowed to speculate as to which of the two conditions was the approximate cause of the injuries, and so the plaintiff should be non-suited. ${ }^{3}$

In the case above referred to, for two years prior to the accident there had been a bank of earth adjoining the sidewalk, and the rain and frost had forced upon the sidewalk sand, gravel and stone until the flagging was entirely covered, the deposit sloping about one inch to the foot from the outer edge of the walk to the curb. Snow and ice had also for a long time accumulated upon this slope. The night before the plaintiff fell chere was a rainfall, the rain freezing as it fell, forming a new coating of ice, and rendering all of the streets in the city slippery and travel dangerous. It was held that in the absence of evidence showing that the slope of the walk, or the old snow and ice, was a concurrent cause without which the accident would not have happened, the plaintiff could not recover and that it was an error to submit the question to the jury to speculate upon, and that there was nothing in the case pointing to the slope as a concurrent cause, beyond the bare fact that it existed, and so nothing to redeem the inference from the domain of mere guess and speculation.

The court also held that the rule is well settled in New York "that the defect, even when a concurrent cause, must be such that without its 'operation the accident would not have happened"; that where there is any other cause for which no one is responsible, "the plaintiff must fail if his evidence does not show that the damage is produced by the former cause," and that "he must fail also, if it is just as probable that the injury came from one cause as the other, because he is bound to make out his case by a preponderance of evidence and the jury must not be left to a mere conjecture or to act upon bare possibility. In this case that rule is violated. The plaintiff slipped upon the ice. That by itself was a sufficient, certain and operating cause of the, fall. No other explanation is needed to account for what happened. It is possible that the slope of the walk had something to do with it. It is equally possible that it did not. There is not a particle of proof that it did. To affirm it is a pure guess and an absolute speculation. Are we to send it to the jury for them to imagine how it might have happened? The great balance of probability is that the ice was the efficient cause. There

\footnotetext{
8 Taylor $v$. the City of Yonkers, 105 N. Y., 202.
} 
is no probability not wholly speculative that the slope was also such. * * No knowledge or intelligence can determine or ascertain that the slope had any part or share in the injury, and to send the question to the jury is simply to let them guess at it, and then upon that guess to sustain a verdict for damages."

The court said in this same case that it was willing to hold cities and villages to a reasonable performance of their duty, but was not willing to make them insurers by founding their liability upon mere possibilities.

The question of contributory negligence frequently arises in this class of negligence cases. The fact, however, that an embankment of snow and ice is visible to the plaintiff and that he does not see fit to walk elsewhere than on the sidewalk, is not of itself such negligence on the part of the plaintiff that he could not recover.

In the case of Pomfrey $v$. the Village of Saratoga Springs, I04 N. Y. 459, the defendant requested the court to charge the jury, "That if the obstruction was visible and apparent to any passerby, the plaintiff was guilty of negligence in attempting to cross it," and also that "if the defect complained of was such as would be seen by any ordinary person passing along the street, it was negligence for the plaintiff to attempt to pass over the defect, but she should have gone around the same." This the court refused to do and the Court of Appeals held that it would not have been proper for the court to have charged as a matter of law that it was negligence for the plaintiff, in the circumstances, to endeavor to pass over the embankment, and a refusal to so charge was not error.

So it is not negligence for a person to walk upon an icy sidewalk without rubbers. As no one is bound to anticipate that the sidewalks are in a dangerous condition, those using them have the right to assume that they are in proper and safe condition, and also the right to use them in the usual manner.

It is noteworthy that the Pennsylvania courts hold a much stricter doctrine on this point, and deem it the duty of a person approaching a sidewalk which he sees to be icy, to go out into the street. or even around the block, to avoid it. 